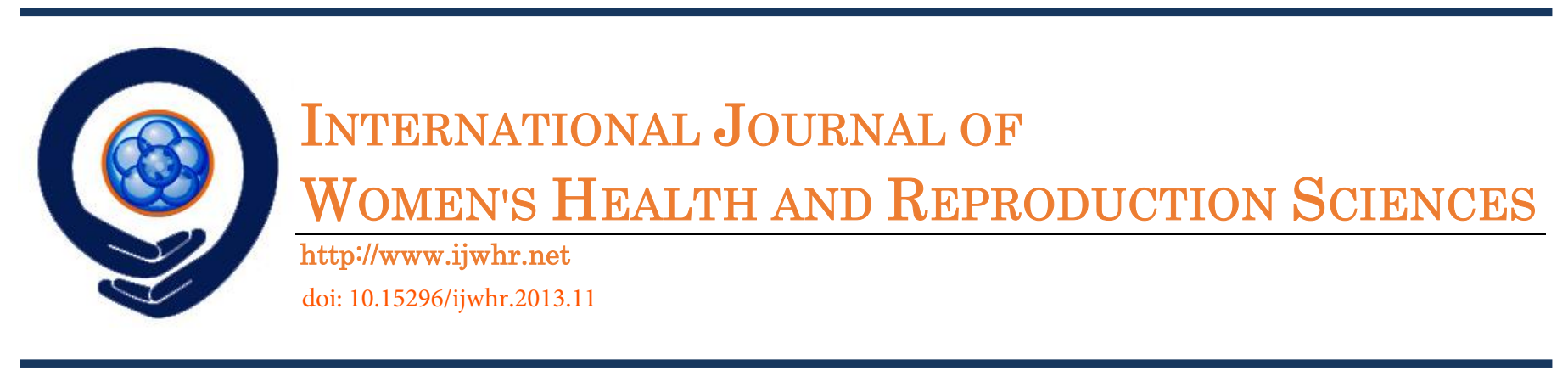

\title{
Evaluation of Testosterone and Alkaline Phosphatase Activity Changes in Epidydimis of Toxoplasma gondii Infected Rats
}

\author{
Fatemeh Afshari 1, Amir Mahdi Imani2 ${ }^{*}$, Sasan Najjari Asl ${ }^{3}$, Hossein H.Farhang 3 , \\ Khazar Ghasempour ${ }^{4}$, Amir Ezzatzadeh ${ }^{3}$, Nava Ainechi ${ }^{1}$
}

\section{Article History:}

Received April 2013

Accepted May 2013

Available online July 2013

\section{Keywords:}

Alkaline Phosphatase

Epididymis

Malondialdehyde

Testosterone

Toxoplasma gondii

\section{Corresponding Author:}

Amir Mahdi Imani, Young Researchers and Elite Club, Tabriz Branch, Islamic Azad University, Tabriz, Iran.

Tel: +989143105465

Email: imaniiie@gmail.com

\begin{abstract}
Objective: Toxoplasma gondii is a widespread protozoan parasite that infects a broad range of warm blooded animals and humans. The present study was investigated to evaluate testosterone, alkaline phosphatase activity and malondialdehyde in male rats experimentally infected by Toxoplasma gondii, RH strain.

Material \& Methods: Male Wistar rats $(n=20)$ were allocated into two groups, group one $(n=10)$ that received $0.6 \mathrm{cc}$ tachyzoites of T. gondii intraperitoneally (I.P.), and control group $(n=10)$ that received nothing. Animals were kept in standard conditions. 30 days after inducing Toxoplasma infection, 5cc blood was collected for assessment of serum testosterone, alkaline phosphatase and malondialdehyde levels. Epididymis tissues of Rats in whole groups were removed and prepared for analysis.

Results: Alkaline phosphatase, and Testosterone were significantly increased in group that was infected by T.gondii in comparison to control group $(\mathrm{P}<0.05)$. There was no significant difference in mean concentration of Malondialdehyde level in infected group in comparison to control group ( $\mathrm{p}>0.05)$.

Epididymis weights in toxoplasmosis group was significantly decreased in comparison to control group $(\mathrm{P}<0.05)$. Positive brown alkaline phosphatase were observed in epididym tissue of infected toxoplasma group in comparison to control group. Conclusion: This study showed that $\mathrm{T}$. gondii has augmenter effects on alkaline phosphatase activity, testosterone and has harmful effect on epididymis tissue.
\end{abstract}

1- Department of Histopathology, Tabriz Branch, Islamic Azad University, Tabriz, Iran.

2-Young Researchers and Elite Club, Tabriz Branch, Islamic Azad University, Tabriz, Iran.

3-Department of Veterinary Pathology, Tabriz Branch, Islamic Azad University, Tabriz, Iran.

4- Medicine Student, Tabriz University of Medical Sciences , Tabriz , Iran. 


\section{Introduction:}

Toxoplasmosis is a zoonotic infection of animals and human caused by the protozoan parasite Toxoplasma gondii. Although $\mathrm{T}$. gondii infects all warm-blooded animals, this infection does not cause clinical illness in the majority of animal species. Toxoplasma gondii is an obligate intracellular parasite that has a sexual cycle in felidae and a twostage asexual cycle in all warm-blooded animals. It predominantly comprises three clonal lineages (I, II and III). The primary host is the felidae (cat) family. Animals are infected by eating infected meat, by ingestion of feces of a cat that has recently been infected, and by transmission from mother to fetus (1). Up to one third of the world human population is estimated to carry a toxoplasma infection (2). In several studies, T. gondii has been isolated from caprine (3), ovine (4), bovine (5), swine (6) and human (7) semen; however, there is no risk of venereal transmission (8). Other reports indicate that Toxoplasma can increase the number of son (9), height in infected men and change personality factors in men and women (10). It is likely that sexual hormone changes can play an important certain role in relation with Toxoplasma and aforementioned phenomena. Patients suffer from chronic toxoplasmosis are taller than uninfected ones, and sexual hormones concentration, testosterone, is higher than uninfected people, and also sexual maturity age of infected men is lower that uninfected men (11). The aim of this study was to investigate the effect of toxoplasmosis on the parameters, including alkaline phosphatase, testosterone, malondialdehyde and epididymis in male rats experimentally infected by T. gondii,

\section{Material \& Methods:}

Experimental Animals :

Adult male Wistar albino rats $(n=20)$ were included in the present study. The rats were 8 weeks old weighing $250 \pm 10 \mathrm{~g}$ each. They were obtained from animal facility of Pasture Institute of Iran. Male rats were housed in temperature-controlled rooms $\left(25^{\circ} \mathrm{C}\right)$ with constant humidity $(40-70 \%)$ and $12 \mathrm{~h} / 12 \mathrm{~h}$ light/ dark cycle before doing experimental protocols. All animals were treated in accordance to the Principles of Laboratory Animal Care [NIH]. All rats were fed with a standard diet and water. The rats were randomly divided into control $(n=10)$ and toxoplasma infected $(n=10)$ group. At the end of the study the rats were killed with carbon dioxide.

\section{T. gondii Infection :}

Tachyzoites of $\mathrm{T}$. gondii $\mathrm{RH}$ strain were maintained by passage in mice every 3 days. Tachyzoites were collected from the peritoneal cavity of infected mice and used to inoculate to experimental rats. The rats were intra-peritoneally injected with 107 tachyzoites of $\mathrm{T}$. gondii in animal house at the Department of Vet pathology in Islamic Azad University, Tabriz Branch, Tabriz, Iran (12) .

\section{Surgical Procedure :}

In thirtieth day, the Pentobarbital sodium $(40 \mathrm{mg} / \mathrm{kg})$ was administered intraperitoneal for anesthesia. Thereafter, the peritoneal cavity was opened through a lower transverse abdominal incision. Thereafter, epididymis in both control and experimental group were immediately removed. The epididymis weights of both groups were registered. The animals were decapitated between 9:00 AM and 11:00 AM, and blood samples were obtained. Blood samples were centrifuged at $4^{\circ} \mathrm{C}$ for $10 \mathrm{~min}$ at $250 \mathrm{~g}$ and the obtained serum were stored at $-20^{\circ} \mathrm{C}$ until used.

\section{Serum Total Testosterone:}

concentrations of total testosterone were measured by using a double antibody radioimmunoassay (RIA) kit (Immunotech Beckman Coulter Co., Los Angeles, CA, USA). The assay sensitivity per tube was 0.025 ng/mL (13).

\section{Malondialdehyde (MDA) Activity Measurement in serum :}

Free radical damage was determined by specifically measuring malondialdehyde (MDA). MDA was formed as an end-product of lipid peroxidation, which was treated with thiobarbituric acid to generate a colored product measured at $532 \mathrm{~nm}$ (MDA detection kit from Nanjing Jiancheng Bioengineering Institute, China).

Assay of ALP Activity in Serum : 
$20 \mu \mathrm{L}$ of serum was added to each well, together with $125 \mu \mathrm{L}$ of the kit's assay buffer, and incubated for $3 \mathrm{~h}$ at room temperature. After three washing steps, p-nitrophenyl phosphate was added for another incubation step of $30 \mathrm{~mm}$, the reaction being stopped with $1 \mathrm{~mol} / \mathrm{L} \mathrm{NaOH}$. The calibrators had concentrations of $0,2,10,20,50$, and $80 \mathrm{U} / \mathrm{L}$ ALP. One unit $(1 \mathrm{U})$ represents $1 \mu \mathrm{mol}$ of $\mathrm{p}$ nitrophenyl phosphate hydrolyzed per minute at $25^{\circ} \mathrm{C} 2$-amino-2 -methyl- 1propanol buffer. A calibration curve was constructed by linear interpolation between the plotted analytical results. All analyses were done in duplicate (CV between duplicates 3-7\%). Reference interval data, determined during the course of these studies, are presented in Results.

\section{Assay of ALP Activity in Epididymis :} Tissue preparation :

The samples were obtained from the Epididymis for carrying out the ALP-activity. The samples immediately were fixed in formaldehyde and then were embedded in paraffin wax, and after preparation of $5-\mu \mathrm{m}$ section, the sections were prepared for the study of ALP activity .The evaluation of enzyme ALP was carried out by Gomori technique (14).The samples were incubated in $ß$ glycerophosphate as substrate, at $37^{\circ} \mathrm{C}$ for $6 \mathrm{~h}$. After washing of samples with water, they were incubated in $2 \%$ nitrate cobalt for 2 min, then washed with water, and were incubated in $1 \%$ ammonium sulfide. The counter staining was done by safranin. Intensity of ALP activity was measured by graded eye piece for all the groups.

\section{Statistical Analysis :}

Statistical comparisons were made using the T-test for comparison of data in the control group and the experimental group. The results were expressed as mean \pm S.E.M (standard error of means). Significant differences were written in parentheses.

\section{Results: \\ Weight of Individual Male Epididymis :}

The obtained results in this study were illustrated in Table 1. There was significant difference in Epididymis weights between T. gondii groups as compared to the control group $(\mathrm{p}<0.05)$ (Table 1$)$.

\section{Results of Malondialdehyde concentration} measurement in serum :
The mean concentration of MDA level didn't show statistically significant difference in T.gondii infected group in comparison to control group ( $\mathrm{p}>0.05)$.

Results of Testosterone levels :

Level of testosterone was significantly increased in T. gondii group as compared to control group $(\mathrm{p}<0.05)$.

\section{Results of Alkaline Phosphatase in Serum :}

Level of Akaline phosphatase was significantly increased in $\mathrm{T}$. gondii group as compared to control group $(\mathrm{p}<0.05)$.

\section{Discussion:}

T. gondii infection is associated with a wide spectrum of clinical pictures in men and women. It has been well documented that toxoplasmosis is of crucial importance especially for pregnant women and immunocompromised patients. In addition to the risks of gestational complications and congenital infections, it has been suggested that toxoplasmosis has some unfavorable effects on reproductive capacity in both men and women (15). The data obtained from limited studies performed in animal models and infertile couples have supported the relationship between toxoplasma and infertility It was revealed that interferon-c (INF-c) plays an important role in preventing the reactivation of T. gondii. CD8positive $\mathrm{T}$ cells were reported as sources of IFN-c during chronic T. gondii infection preventing reactivation. $(16,17,18,19)$. It was also reported that interleukin-12 (IL-12) is required for the maintenance of IFN-c production of $\mathrm{T}$ cells during chronic $\mathrm{T}$. gondii infection (20).

Alkaline phosphatase is a hydrolase enzyme responsible for removing phosphate groups from many types of molecules, including nucleotides, proteins, and alkaloids (21). This enzyme has effective role in many tissues, such as liver, bowel, kidney, bone, placenta and reproductive tract (22). There are three isoenzymes of ALP, including the placental alkaline phosphatase, intestinal, and Osteohepatic (liver, bone, kidney). The basic difference among these isoenzymes is related to gluco-proteins generated by them. These isoenzymes have different roles based on glucoprotein type in their structures (23). In male reproduction tract, ALP is secreted in prostate and testes (24) Seminal fluid 
quality could be determined by isoenzymes of ALP (25). Effectiveness role of alkaline phosphatase is seen in Leyding cell, transitional and Fibroblast in seminiferous tubules (26). Malondialdehyde (MDA) is the most abundant lipid peroxides, as indicative of oxidative stress in cells and tissues (27). Therefore, measurements of MDA, is widely used as indicator of lipid peroxidation, and increased levels of lipid peroxidation products have been associated with a variety of chronic diseases in both human and model system (28).

The present results clearly indicate that testosterone were significantly increased in groups that were infected with $\mathrm{T}$. gondii in comparison to control group $(\mathrm{P}<0.05)$.

Previous studies on human which is done by Shirbazou $\mathrm{S}$ et al and Jaroslav Flegr demonstrated that there is a direct relation between Toxoplasma infection and testosterone increase in blood plasma (29, 30) but A.M.A Barakat's results showed that there was significant decrease in serum testosterone level in New Zealand Rabbit (31).

Also this present showed that AlP were significantly increased in groups that were infected with $\mathrm{T}$. gondii in comparison to control group $(\mathrm{P}<0.05)$. Jungersen et al showed that Serum levels of alkaline phosphatase and the acute phase protein haptoglobin were decreased or increased, respectively, in response to the toxoplasma gondii infection. (32)

The results obtained from this study showed that there was no significant difference in mean concentration of malondialdehyde level in infected group in comparison to control group $(\mathrm{p}>0.05)$. Khaki et al confirmed our findings(33).

Epididymis weights in toxoplasma group was significantly decreased in comparison to control group $(\mathrm{P}<0.05)$. Khaki et al showed that There was significant difference in testes weights between $\mathrm{T}$. gondii groups as compared to the other groups $(\mathrm{p}<0.05)(33)$.

\section{Conclusion :}

In our study, T.gondii had significant effect on testosterone, alkaline phosphatase and Epididymis weight . T.gondii increased ALP and Testosterone, but decreased epididymis weight and did't have significant effect on MDA in infected group. White rats, which are considered to be the best model for human toxoplasmosis due to their natural resistance to Toxoplasma infection, may be used for further investigation on the possible effect of toxoplasmosis on male fertility.

\section{Acknowledgments:}

Thanks go to Dr.Afshari for performing histopathological studies in Histopathology laboratory of Tabriz Islamic Azad University, Faculty of Medical Sciences.

Figures:

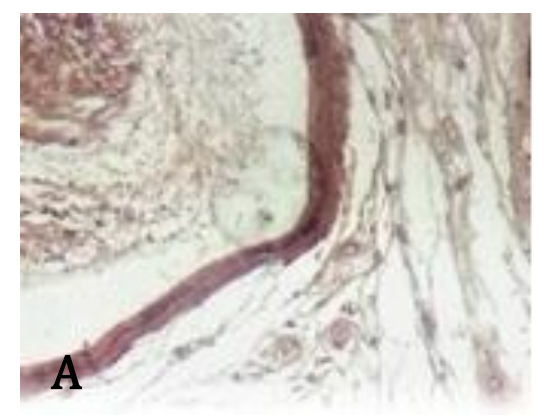

Figure (A) Photomicrograph of Epididymis tissue that staining with alkaline phosphatase, Control group (X320).

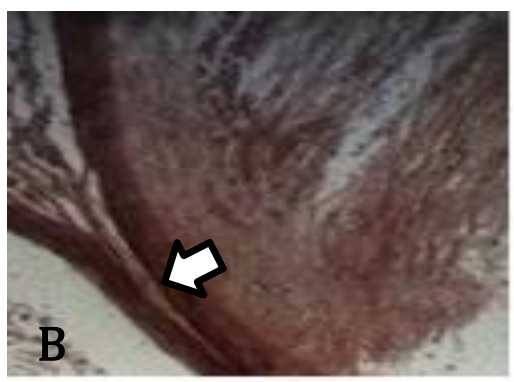

Figure (B): Photomicrograph of Epididymis tissue that staining with alkaline phosphatase, Positive brown color were observed in infected group with $0.6 \mathrm{cc}$ Toxoplasma gondii, (X320).

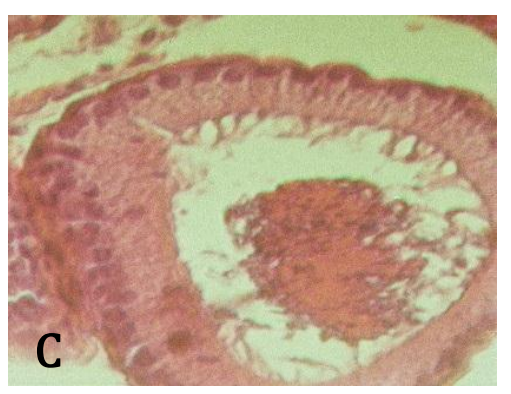

Figure (C): Photomicrograph of Epididymis tissue showed normal structural in control group, $\mathrm{H} \& \mathrm{E}(\mathrm{X} 320)$. 


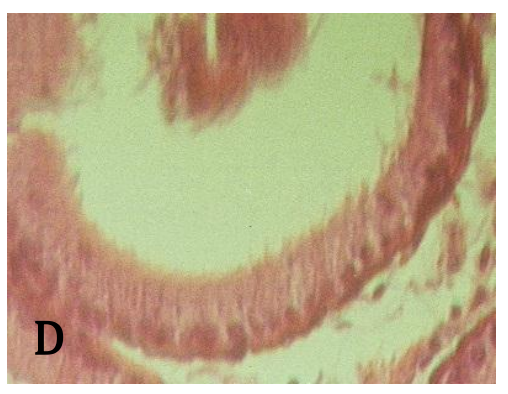

Figure (D): Photomicrograph of Epididymis tissue showed lose of microvilli in infected group with 0.6 cc Toxoplasma gondii, $\mathrm{H} \& \mathrm{E}(\mathrm{X} 320)$

Table 1. The effect of Toxoplasma gondii on Testosterone, Malondialdehyde and Epididymis weight of control and T. gondii infected group in the rats.

\begin{tabular}{lll}
\hline Group & Control & T.gondii \\
\hline Epididymis $(\mathrm{g})$ & $1.41 \pm 0.57$ & $1 \pm 0.57 *$ \\
Testosterone $(\mathrm{ng} / \mathrm{ml})$ & $1.24 \pm 0.13$ & $1.68 \pm 0.13 *$ \\
Alkaline Phosphatase & $61.25 \pm 2.81$ & $108.75 \pm 6.12 *$ \\
Malondialdehyde $(\mathrm{mmol} / \mathrm{ml})$ & $3.73 \pm 0.57$ & $3.93 \pm 0.57$ \\
\hline Data are presented as mean + SE *Significant different at P<0.05 level (compared with the control group)
\end{tabular}




\section{References:}

1. Torda A.Toxoplasmosis. Are cats really the source? Aust. Fam. Physician, 2001; 30 (8): 743-747.

2. Montoya J, Liesenfeld O. Toxoplasmosis. Lancet. 2004; 363(9425):1965-1976.

3. Dubey, J.P., Sharma, S.P. Prolonged excretion of Toxoplasma gondii in semen of goats. American Journal of Veterinary Research .1980; 41, 794-795.

4. Anga, A.O., Umoh, J.U., Kyewalabye, E.K., Ekwempu, C.C. Comparative experimental transmission studies with Nigerian isolates and TS-I strain of Toxoplasma gondii in sheep. Journal of Animal Production Research. 1988; 8, 104-120.

5. Scarpelli, L.C. Viabilidate da transmissão venérea do Toxoplasma gondii em bovinos. Dissertação de Mestrado, FCAV, Universidade Estadual Paulista, Jaboticabal, SP.2001; 128.

6. Moura, A.B., Costa, A.J., Filho, S.J., Paim, B.B., Pinto, F.R., Di Mauro, D.C.Toxoplasma gondii in semen of experimentally infected swine. Pesquisa Veterinaria Brasileira. 2007; $27: 430-434$.

7. De Paepe, M.E., Guerrieri, C., Waxman, M. Opportunistic infections of the testis in the acquired immunodeficiency syndrome. Mount Sinai Journal of Medicine.1990; 57: 25-29.

8. Janitschke, K., Nürnberger, F. Studies on the significane of sexual intercourse for the transmission of Toxoplasma gondii. Zentralblatt fur Bakteriologie 1975; 231: 323-332.

9. Saebi E. Parasite diseases in Iran. 6th ed, Tehran, Cultural Institute. 1998; 251-41.

10. Ghorbani M, Edrissian GW, Afshar A. Serological survey of north west and sought west part of Iran. Med Hygn. 1981; 75: 3840.

11. Jones JL, Ogunmodede F, Schftel J, Kirkland E. Toxoplasmosis-related knowledge and practices among pregnant women in the United States. Infect Dis Obstet Gynecol. 2003;11: $139-45$.

12. Berdoy M, Webster JP, Macdonald DW. Fatal attraction in rats infected with Toxoplasma gondii. Proc. Biol. Sci. 2000; 267(1452):1591-1594.

13. Huang HFS, Linsenmeyer TA, Li MT, Giglio W, Anesetti R, von Hagen J, Ottenweller JE, Pogach L. Acute effects of spinal cord injury on the pituitary-testicular hormone axis and Sertoli cell functions: a time course study. J Androl. 1995;16: 148-157.

14. Bancraft JD, Ganble M. Theory and practice of histological techniques. 5 th ed. London; Churchill Livigstone; 2002.

15. Aral Akarsu G, Elhan HA, Akarsu C. Retrospective evaluation of Toxoplasma gondii seropositivity in fertile and infertile women.Mikrobiyol. Bul. 2011; 45(1):174-80. 
16. Kang H, Suzuki Y. Requirement of non-T cells that produce gamma interferon for prevention of reactivation of Toxoplasma gondii infection in the brain. Infect Immun 2001; 69(5):2920-2927.

17. Wang $\mathrm{X}$, Kang $\mathrm{H}$, Kikuchi $\mathrm{T}$, Suzuki Y. Gamma interferon production, but not perforinmediated Cytolytic activity, of $\mathrm{T}$ cells is required for revention of toxoplasmic encephalitis in BALB/c mice genetically resistant to the disease. Infect mmun. 2004; 72(8):4432-4438.

18.Wang X, Claflin J, Kang H, Suzuki Y. mportance of CD8(+)Vbeta8(+) T cells in IFNammamediated prevention of toxoplasmic encephalitis in genetically resistant BALB/c mice. $J$ nterferon Cytokine Res 2005; 25(6):338-344.

19. Wang X, Michie SA, Xu B, Suzuki Y. mportance of IFN-gamma-mediated expression of endothelial VCAM-1 on recruitment of CD8+ T cells into the brain during chronic infection with Toxoplasma gondii. J Interferon Cytokine Res 2007; 27(4):329-338.

20. Yap G, Pesin M, Sher A. Cutting edge: IL-12 is required for the maintenance of IFNgammaproduction in $\mathrm{T}$ cells mediating chronic resistance to the intracellular pathogen, Toxoplasma gondii. J Immunol 2000; 165(2):628-631.

21. Tamás L, Huttová J, Mistrk I, Kogan G. Effect of Carboxymethyl Chitin-Glucan on the Activity of Some Hydrolytic Enzymes in Maize Plants. Chem. Pap. 2002; 56 (5): 326-329.

22. Zakrzewska H, Udala J, Blaszczyk B. In vitro influence of sodium fluoride on ram semen quality and enzyme activities. Fluoride. 2002; 35: 153-160.

23. Seargeant LE, Stinson R A. Evidence that three structural genes code for human alkaline phosphatase. Nature. 1979; 281: 152-154.

24. Lewis-Jones D I, Johnson P M, Desmond A D, McLaughlin P J. Germ cell alkaline phosphatase in human seminal plasma following vasectomy. Br J Urol.1992; 69: 418-420.

25. Kutzler M A, Solter PF, Hoffman W E, Volkmann D H. Characterization and localization of alkaline phosphatase in canine seminal plasma and gonadal tissues. Theriogenology. 2003; 60:299-306.

26. Gunawardana VK. Ultrastructural localization of alkaline phosphatase in intertubular tissue of the testis in domestic fowl. Tissue cell. 1990; 22:113-121.

27. Draper HH, Hadley M. A review of recent studies on the metabolism of exogenous and endogenous malondialdehyde. Xenobiotica. 1990; 20:901-907.

28. Romero FJ, Bosch-Morell F, Romero MJ, Jareno EJ, Romero B, Marin N, Roma J. Lipid peroxidation products and antioxidants in human disease. Environ Health Perspect. 1998;106:1229-1234.

29. Shirbazou S, Abasian L, Talebi Meymand F. Effects of Toxoplasma gondii infection on 
plasma testosterone and cortisol level and stress index on patients referred to Sina hospital, Tehran.Jundishapur J Microbiol. 2011; 4(3): 167-173.

30. Jaroslav Flegr. Effects of Toxoplasma on Human Behavior Schizophrenia Bulletin 2007; 33(3): 757-760

31. A.M.A Barakat.Some diagnostic studies on male New Zealand rabbit experimentally infected with Toxoplasma gondii strain. Global veterinaria 2007 ; 1 (1): 17-23.

32. Jungersen G, Jensen L, Riber U, Heegaard PM, Petersen E, Poulsen JS, Bille-Hansen V, Lind P. Pathogenicity of selected Toxoplasma gondii isolates in young pigs. Int $\mathrm{J}$ Parasitol. 1999; 29(8):1307-19.

32. Khaki A, Farzadi L, Ahmadi Sh, Ghadamkheir E, Khaki AA, Shojaee S, Sahizadeh R. AJPP 2011; 5(7): 903-907 